\title{
Germline Mutations of the PTEN/MMAC1 Gene in Japanese Patients with Cowden Disease
}

\author{
Takashi Kohno, ${ }^{1}$ Mina Takahashi, ${ }^{1}$ Takashi Fukutomi, ${ }^{2}$ Kyosuke Ushio ${ }^{3,4}$ and Jun Yokota ${ }^{1,5}$ \\ ${ }^{1}$ Biology Division, National Cancer Center Research Institute, ${ }^{2}$ Department of Surgical Oncology and \\ ${ }^{3}$ Department of Diagnostic Radiology, National Cancer Center Hospital, 1-1, Tsukiji 5-chome, Chuo-ku, \\ Tokyo 104-0045
}

Cowden disease (CD) is an autosomal dominant disorder which confers a high susceptibility to diverse benign and malignant tumors. The PTEN/MMAC1 gene was identified as being responsible for CD, since its germline mutations have been identified in affected individuals in the United States and Europe. We identified three novel germline PTEN mutations, a 2-bp deletion, a 1-bp insertion and a missense mutation, in three of five Japanese patients with $C D$. The missense mutation resided outside of the region encoding a putative phosphatase domain of the predicted PTEN protein, where previously reported missense mutations in CD patients have been clustered. The present result suggests that a wide range of germline PTEN mutations may play a role in the pathogenesis of $\mathrm{CD}$.

Key words: Cowden disease — PTEN — Germline mutation — Breast cancer

Cowden disease (CD) is an autosomal dominant cancer predisposition syndrome associated with an elevated risk for tumors of the breast, thyroid and skin. ${ }^{1)}$ The common feature of this disease is a predisposition to hamartomas, which are benign tumors containing differentiated but disorganized cells indigenous to the tissue of origin. Linkage analysis has indicated that a single locus within chromosome $10 \mathrm{q} 23$ is likely to be responsible for the disease. ${ }^{2)}$ The PTEN/MMACl gene, which encodes a protein tyrosine/serine/threonine phosphatase, was identified as a tumor suppressor gene at $10 \mathrm{q} 23.3$, that is inactivated in various types of human tumors, including glioblastoma, prostate cancer, malignant melanoma, endometrial carcinoma, and lung cancer. ${ }^{3-6}$ Recently, this gene was also identified as being responsible for $\mathrm{CD}$, since germline mutations have been identified in affected individuals of CD families in the United States and Europe. ${ }^{7-10)}$ Furthermore, it was revealed that the wild-type allele of the PTEN gene was lost in tumors of CD patients with germline PTEN mutations. ${ }^{11)}$ Therefore, inactivation of both alleles of the PTEN gene, conforming to Knudson's "2hit" model, ${ }^{12}$ ) should be responsible for tumorigenesis in CD patients. Up to the present, $56 \mathrm{CD}$ families/patients have been examined for PTEN alterations, and 23 were found to carry germline PTEN mutations. Seventeen of them had nonsense or frameshift mutations leading to premature termination of the PTEN protein, while 5 had missense mutations. The remaining one had a splice site

${ }^{4}$ Present address: National Kyushu Cancer Center, Notame 3-11, Minami-ku, Fukuoka 815.

${ }^{5}$ To whom correspondence should be addressed. mutation. Information on germline PTEN mutations in patients with $\mathrm{CD}$ should be accumulated so as to define the spectrum of PTEN mutations associated with $\mathrm{CD}$ and thereby to understand the pathogenic significance and etiologic role of PTEN mutations in CD.

More than forty cases of $\mathrm{CD}$ have been reported in Japan. ${ }^{13)}$ However, PTEN mutations have not yet been investigated in Japanese patients with $\mathrm{CD}$. In the present study, we examined PTEN germline mutations in five Japanese patients with $\mathrm{CD}$. After having obtained informed consent, we collected blood samples from one familial (patient \#1) and 4 sporadic (patients \#2-5) CD patients, who were diagnosed based on the criteria formulated by the international CD consortium (Table I). An abridged pedigree of the $\mathrm{CD}$ family including patient \#1 is shown in Fig. 1. All the patients showed multiple polyps in the gastrointestinal tract, as well as multiple facial trichilemmomas, which are one of the major criteria for the diagnosis of $\mathrm{CD}$. Four patients had multiple adenomas of the thyroid, and three of them were affected by breast cancers.

Genomic DNA was extracted from blood samples by proteinase $\mathrm{K}$ digestion and phenol-chloroform extraction, and polymerase chain reaction-single strand conformation polymorphism (PCR-SSCP) analysis was performed using 9 sets of primers which amplified exons 1-9.6) Three cases, patients \#1-3, showed bands with distinct electrophoretic mobilities in exons 6, 4 and 5, respectively (Fig. 2A). Direct sequencing analysis revealed that these three patients were heterozygous for the alleles of mutations leading to changes in the predicted PTEN/MMACl gene products (Fig. 2B, Table I). Patients \#1 and \#2 had frame- 
Jpn. J. Cancer Res. 89, May 1998

Table I. Clinical Features and PTEN Mutations in Japanese Patients with Cowden Disease

\begin{tabular}{|c|c|c|c|c|c|c|c|c|c|}
\hline Patient & Sex & Age & Skin & Thyroid & Breast $^{a)}$ & Gastrointestinal tract & Others & Mutation & Predicted effect \\
\hline 1 & $\mathrm{~F}$ & 56 & $\begin{array}{l}\text { trichilemmomas } \\
\text { fibroma }\end{array}$ & $\begin{array}{l}\text { multiple } \\
\text { adenomas }\end{array}$ & cancer (53) & multiple polyps & & $\begin{array}{l}\text { del AT in Y177 } \\
\text { (exon 6) }\end{array}$ & frameshift \\
\hline 2 & M & 49 & trichilemmomas & & & multiple polyps & & $\begin{array}{l}\text { ins } \mathrm{T} \text { in } \mathrm{N} 82 \\
\text { (exon } 4)\end{array}$ & frameshift \\
\hline 3 & M & 46 & $\begin{array}{l}\text { trichilemmomas } \\
\text { angioma }\end{array}$ & $\begin{array}{l}\text { multiple } \\
\text { adenomas }\end{array}$ & & multiple polyps & macrocephaly & $\begin{array}{l}\mathrm{C} \text { to } \mathrm{T} \text { in } \mathrm{H} 93 \\
\text { (exon } 5 \text { ) }\end{array}$ & $\mathrm{H}$ to $\mathrm{Y}$ \\
\hline 4 & $\mathrm{~F}$ & 47 & $\begin{array}{l}\text { trichilemmomas } \\
\text { lipoma }\end{array}$ & $\begin{array}{l}\text { multiple } \\
\text { adenomas }\end{array}$ & cancer (36) & multiple polyps & & ND & \\
\hline 5 & $\mathrm{~F}$ & 62 & $\begin{array}{l}\text { trichilemmomas } \\
\text { angioma }\end{array}$ & $\begin{array}{l}\text { multiple } \\
\text { adenomas }\end{array}$ & cancer (62) & multiple polyps & $\begin{array}{l}\text { endometrial } \\
\text { cancer }\end{array}$ & ND & \\
\hline
\end{tabular}

M, male; F, female; ND, not detected.

a) Ages at diagnosis are shown in parentheses.

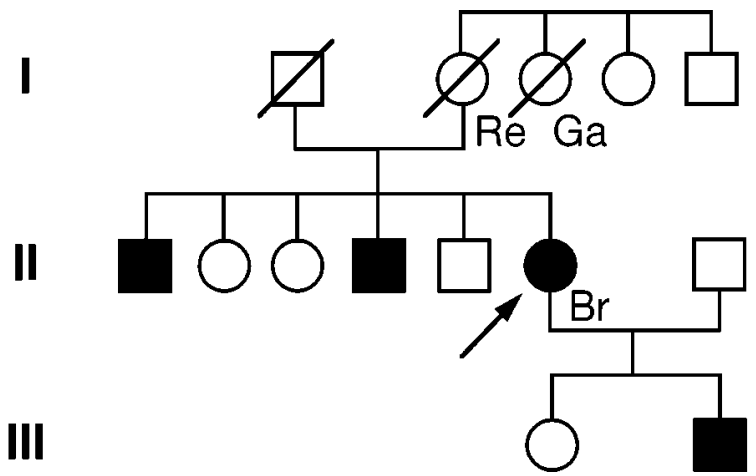

Fig. 1. Abridged pedigree of a Japanese CD family. Squares and circles indicate male and female, respectively. Filled symbols indicate members evaluated as having features of $\mathrm{CD}$. Roman numerals indicate generation numbers, and an arrow indicates the proband. The following abbreviations are used for the cancer types: $\mathrm{Br}$, breast cancer, $\mathrm{Ga}$, gastric cancer; and $\mathrm{Re}$, rectal cancer.

Fig. 2. Germline PTEN mutations in Japanese CD patients. A, PCRSSCP analysis. Results for exons 4, 5, and 6 are shown. B, Direct sequencing. PCR products were purified using a QIA quick-spin PCR purification kit (QIAGEN Inc.), and directly sequenced using the 373S DNA sequencer with a DNA sequencing kit (Applied Biosystems). All PCR products were sequenced in both directions. A 2-bp deletion in codon 177 was detected in patient \#1, while a 1-bp insertion in codon 82 was detected in patient \#2. In patient \#3, a C-to-T transition in codon 93 was detected (reverse sequence). The mutated regions are underlined.
A

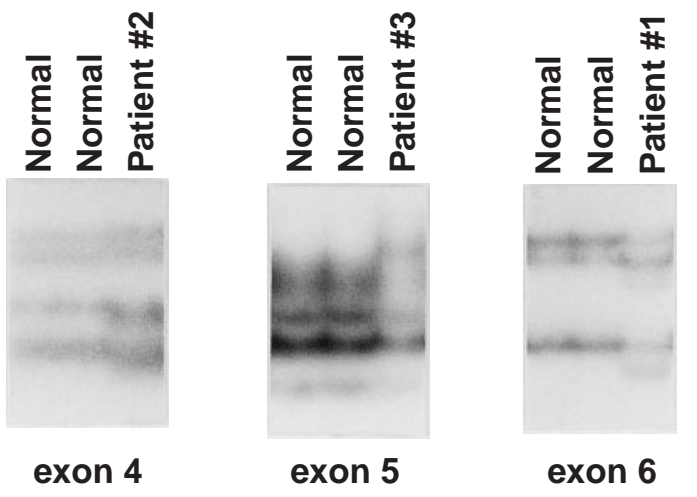

B Patient \#1

GTATTATTATAGC
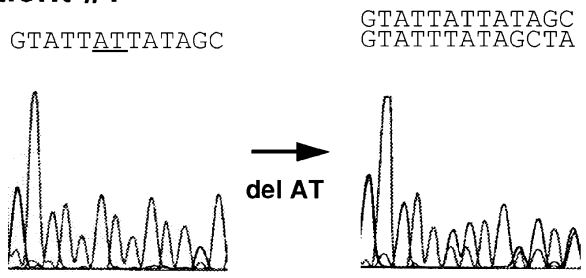

\section{Patient \#2}

AAATTTAATTGCA
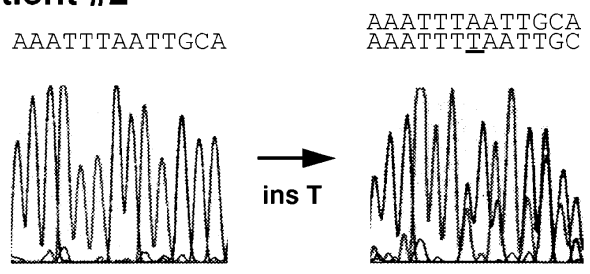

\section{Patient \#3}

GGTTATGGTCTTC
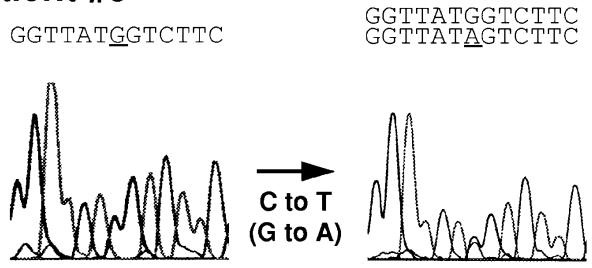
shift mutations in codons 177 and 82, which caused premature termination of the protein. Patient \#3 showed a sequence variation in codon 93 , which caused a change of an amino acid residue flanking the putative phosphatase domain. To determine whether the sequence variant in codon 93 represents a germline mutation or a genetic polymorphism, we performed PCR-SSCP analysis of DNA from 50 unrelated Japanese individuals and found no evidence of this variation in 100 alleles. Furthermore, we directly sequenced all exons of the PTEN gene in patient \#3, but no other sequence variation than that in codon 93 was detected. Thus, this variant is likely to be a germline mutation. Patients \#4 and \#5 did not show bands with distinct electrophoretic mobilities in the PCR-SSCP analysis. Therefore, we again sequenced all exons of the PTEN gene, but no sequence variation was detected in these cases.

Three of the 5 Japanese patients with CD carried germline PTEN mutations, indicating that this gene is involved in the pathogenesis of CD in Japan. Up to the present, 22 different types of PTEN mutations have been identified in 23 cases of germline PTEN mutations. ${ }^{7-10)}$ In this study, we have further identified three novel types of PTEN mutations in patients with $\mathrm{CD}$. A missense mutation detected in patient \#3 resided outside the region encoding a putative phosphatase domain of the PTEN gene, where previously reported missense mutations in $\mathrm{CD}$ patients have been clustered. ${ }^{7,9)}$ This result indicates that a wide

\section{REFERENCES}

1) Lloyd, K. M. and Dennis, M. Cowden's disease: a possible new symptom complex with multiple system involvement. Ann. Intern. Med., 58, 136-142 (1963).

2) Nelen, M. R., Padberg, G. W., Peeters, E. A., Lin, A. Y., van den Helm, B., Frants, R. R., Coulon, V., Goldstein, A. M., van Reen, M. M., Easton, D. F., Eeles, R. A., Hodgsen, S., Mulvihill, J. J., Murday, V. A., Tucker, M. A., Mariman, E. C., Starink, T. M., Ponder, B. A., Ropers, H. H., Kremer, H., Longy, M. and Eng, C. Localization of the gene for Cowden disease to chromosome 10q22-23. Nat. Genet., 13, 114-116 (1996).

3) Li, J., Yen, C., Liaw, D., Podsypanina, K., Bose, S., Wang, S. I., Puc, J., Miliaresis, C., Rodgers, L., McCombie, R., Bigner, S. H., Giovanella, B. C., Ittmann, M., Tycko, B., Hibshoosh, H., Wigler, M. H. and Parsons, R. PTEN, a putative protein tyrosine phosphatase gene mutated in human brain, breast, and prostate cancer. Science, 275, 1943-1947 (1997).

4) Steck, P. A., Pershouse, M. A., Jasser, S. A., Yung, W. K., Lin, H., Ligon, A. H., Langford, L. A., Baumgard, M. L., Hattier, T., Davis, T., Frye, C., Hu, R., Swedlund, B., Teng, D. H. and Tavtigian, S. V. Identification of a candidate tumour suppressor gene, MMAC1, at chromosome 10q23.3 that is mutated in multiple advanced cancers. Nat. range of germline PTEN mutations may play a role in the pathogenesis of CD.

PTEN mutations were not detected in two of the five patients with CD. This result is consistent with those of previous studies showing that PTEN mutations are undetectable in a significant proportion of $\mathrm{CD}$ patients, including those from families linked to $10 \mathrm{q} 22-\mathrm{q} 23 .{ }^{7-10)}$ In those cases, mutations might be present in untranslated regions, introns or the promoter region of the PTEN gene. Other mechanisms, including large deletions and methylational silencing, may also be involved in the inactivation of the PTEN gene. Alternatively, it is also possible that CD is a genetically heterogeneous disease, as indicated by a recent linkage study. ${ }^{10)} \mathrm{CD}$ is a complex disease associated with a high risk of developing breast cancer and other lesions, including benign and malignant diseases of the thyroid, intestinal polyps and genitourinary abnormalities. Analysis of PTEN alterations in a large number of CD patients, as well as a search for other genes relevant to $\mathrm{CD}$, will be needed to elucidate the molecular mechanisms of the development of CD.

This work was supported in part by a Grant-in-Aid from the Ministry of Health and Welfare for the 2nd-term Comprehensive 10-Year Strategy for Cancer Control.

(Received February 13, 1998/Revised March 26, 1998/Accepted April 1, 1998)

Genet., 15, 356-362 (1997).

5) Myers, M. P. and Tonks, N. K. PTEN: Sometimes taking it off can be better than putting it on. Am. J. Hum. Genet., 61, 1234-1238 (1997).

6) Kohno, T., Takahashi, M., Manda, R. and Yokota, J. Inactivation of the PTEN/MMAC1/TEP1 gene in human lung cancers. Genes Chromosom. Cancer, 22 (1998), in press.

7) Liaw, D., Marsh, D. J., Li, J., Dahia, P. L., Wang, S. I., Zheng, Z., Bose, S., Call, K. M., Tsou, H. C., Peacocke, M., Eng, C. and Parsons, R. Germline mutations of the PTEN gene in Cowden disease, an inherited breast and thyroid cancer syndrome. Nat. Genet., 16, 64-67 (1997).

8) Lynch, E. D., Ostermeyer, E. A., Lee, M. K., Arena, J. F., Ji, H., Dann, J., Swisshelm, K., Suchard, D., MacLeod, P. M., Kvinnsland, S., Gjertsen, B. T., Heimdal, K., Lubs, H., Møller, P. and King, M. C. Inherited mutations in PTEN that are associated with breast cancer, Cowden disease, and juvenile polyposis. Am. J. Hum. Genet., 61, 1254-1260 (1997).

9) Nelen, M. R., van Staveren, W. C. G., Peeters, E. A. J., Hassel, M. B., Gorlin, R. J., Hamm, H., Lindboe, C. F., Fryns, J.-P., Sijmons, R. H., Woods, D. G., Mariman, E. C. M., Padberg, G. W. and Kremer, H. Germline mutations in the PTEN/MMAC gene in patients with Cowden disease. Hum. Mol. Genet., 6, 1383-1387 (1997). 
10) Tsou, H. C., Teng, D. H., Ping, X. L., Brancolini, V., Davis, T., Hu, R., Xie, X. X., Gruener, A. C., Schrager, C. A., Christiano, A. M., Eng, C., Steck, P., Ott, J., Tavtigian, S. V. and Peacocke, M. The role of MMAC1 mutations in early-onset breast cancer: causative in association with Cowden syndrome and excluded in BRCA1-negative cases. Am. J. Hum. Genet., 61, 1036-1043 (1997).

11) Marsh, D. J., Dahia, P. L., Coulon, V., Zheng, Z., Dorion-Bonnet, F., Call, K. M., Little, R., Lin, A. Y., Eeles, R. A., Goldstein, A. M., Hodgson, S. V., Richardson, A. L., Robinson, B. G., Weber, H. C., Longy, M. and Eng,
C. Allelic imbalance, including deletion of PTEN/ MMACI, at the Cowden disease locus on 10q22-23, in hamartomas from patients with Cowden syndrome and germline PTEN mutation. Genes Chromosom. Cancer, 21, 6169 (1998).

12) Knudson, A. G. Mutation and cancer: statistical study of retinoblastoma. Proc. Natl. Acad. Sci. USA, 68, 820-823 (1971).

13) Amagasa, M., Yuda, F., Tsunoda, T. and Sato, S. Lhermitte-Duclos disease associated with Cowden disease. Brain Tumor Pathol., 14, 63-69 (1997). 